\title{
Studies on the influence of plankton on antibacterial activity of sea water
}

\author{
K. Moebus \\ Biologische Anstalt Helgoland (Meeresstation); \\ Helgoland, Federal Republic of Germany
}

\begin{abstract}
KURZFASSUNG: Untersuchungen über den Einfluß von Plankton auf die antibakterielle Aktivität von Meerwasser. Mit Escherichia coli, Staphylococcus aureus und Serratia marinorubra wurde der Einfluß erhöhten und verminderten Planktongehaltes auf die bakterizide Wirkung von Meerwasser geprüft. S. aureus war der einzige Teststamm, dessen Inaktivation in mit Plankton angereichertem Meerwasser während einiger Experimente deutlich rascher erfolgte als in unbehandelten Parallelproben. Andererseits war dessen Inaktivation in Meerwasser mit stark reduziertem Planktongehalt während derselben Experimente nicht oder kaum geringer als in unbehandeltem Meerwasser. In anderen Versuchen wurde bei diesem Organismus wie auch bei den zwei anderen Teststämmen beobachtet, daß die bakterizide Wirkung von rohem Meerwasser durch Anreicherung mit Plankton entweder nicht signifikant verändert oder aber beträchtlich vermindert wurde. Der für das Uberleben der Testbakterien förderliche Einfluß des Planktons war jeweils dann am stärksten, wenn die antibakterielle Aktivität unbehandelten Meerwassers extrem hoch war. Aus den vorliegenden Ergebnissen wird geschlossen, daß mit der Anreicherung von Plankton keine Vermehrung wirksamer bakterizider Substanz, wohl aber eine Erhöhung der Nährstoffkonzentration im jeweiligen Ansatz verbunden war. Auf der Grundlage kürzlich veröffentlichter Befunde über den Einfluß organischer Nährstoffe auf die antibakterielle Aktivität von Meerwasser werden die dargestellten Ergebnisse diskutiert.
\end{abstract}

\section{INTRODUCTION}

The antibacterial activity of sea water is attributed, at least in part, to bactericidal compounds produced by marine organisms among which planktonic algae probably are most important. Numerous phytoplanktonic species are known to form inhibitory matter under natural and/or laboratory conditions. The literature concerning this subject was summarized by Sreburth (1968) and Aubert et al. (1968), and recent information was presented by Aubert \& Pesando (1969), GaUtHIER (1969) and AUbert \& Jorris (1971). The importance of planktonic algae was also displayed by the observation of seasonal changes in bactericidal capacity of sea water which were correlated with the life cycles of phytoplankton communities (SIERURTH \& PRATT 1962, Moebus 1972a).

Generally, untreated sea water is more active against the test organisms used than corresponding sterilized samples (DE GAIXA 1889, ZoBELL 1936, VACCARo et al. 1950, 
CARLuCCI et al. 1961 and others). Heating of sea water is thought to destroy inhibitory compounds and to result in increased nutrient concentration from killed organisms, thereby causing decreased bactericidal efficacy. Regarding filter-sterilization, retention of dead particles loaded with bactericides, and of viable organisms capable to excrete harmful substances, is assumed to be the reason for reduced antibacterial activity of the filtrate. If so, one should be able to increase the bactericidal capacity of raw sea water by enrichment with living and dead matter present in the sea. This assumption was examined in an investigation reported in this paper.

\section{MATERIALS AND METHODS}

Basic materials and methods used were the same as recently specified by MoEBus (1972a). Sea water always was sampled at station "Kabeltonne" in the channel between the two islands of Helgoland (North Sea). The following procedures were employed for enrichment of sea water with particulate matter:

Enrichment with filter sludge: Two $500 \mathrm{ml}$ portions of raw sea water ( $r s w)$ were filtered through seperate membrane filters of $0.15 \mu$ mean porosity. The filter sludge of both filter disks was scrubbed off by a sterile loop in $10 \mathrm{ml} r s w$ which were added to $100 \mathrm{ml} r s w$ to give 10-fold enriched rsw (ersw10).

Enrichment with viable plankton: Trovidur tubing, about $12 \mathrm{~cm}$ in length and $5 \mathrm{~cm}$ in diameter, was covered with $10 \mu$ mesh Nylon gauze at one end. This device, stored in ethanol $(70 \%)$ for sterilization and rinsed with sterile distilled water before use, was dipped into rsw with the gauze in front. Sea water passing the gauze (10 $\mu$-rsw) was sucked off by means of a pump until the volume of $r s w$ was reduced to $1 / 20$ (erswer $)$. The enrichment procedure was finished after 30 to $60 \mathrm{~min}$ and warranted viability of even rather sensitive planktonic organisms. ersto $0_{20}$ war carefully handled by means of pipettes with open mouth.

Sterile filtrates were prepared at 1 to $2 \mathrm{~mm} \mathrm{Hg}$ vacuum from each $100 \mathrm{ml}$ rsw and $10 \mu-\gamma s w$ ( $f s w$ and $10 \mu-f s w$, respectively) as well as from $50 \mathrm{ml}$ ersw2 $\left(e f s w_{20}\right)$.

Inactivation and growth of bacteria are presented as $\log \left(\mathrm{N}_{\mathrm{X}}-\mathrm{N}_{0}\right)$, where $\mathrm{N}$ is the number of colony formers $/ \mathrm{ml}$ present in the samples after $\mathrm{o}$ and $\mathrm{x}$ days of incubation at $25^{\circ} \mathrm{C}$ in the dark, respectively.

\section{RESULTS}

\section{Effects of filter sludge}

Five experiments of this type were performed during May to July 1970 (started on May 29th, June 5th, 12th, 19th, and July 6th, respectively). Samples of $25 \mathrm{ml} \mathrm{rsw}$ and ersw $_{10}$ were inoculated with $1 \mathrm{ml}$ of test bacterial suspensions (in saline) to attein initial titers of $10^{8}$ cells $/ \mathrm{ml}$ of Escherichia coli, $2 \times 10^{7}$ cells $/ \mathrm{ml}$ of Staphylococcus aureus, and $10^{7} \mathrm{cells} / \mathrm{ml}$ of Serratia marinorubra, respectively. The results obtained after 3 days of incubation are shown in Figure 1. No significant differences between 
the bactericidal capacities of rsw and ersw $w_{10}$ were found in regard to $E$. coli (Fig. 1, section $\mathrm{A}$ ). The inactivation of $S$. marinorubra (section $\mathrm{C}$ ) in ersw $w_{10}$ was either the same as or weaker than in $r s w$. Concerning anti-staphylococcal activity (section B) of $r s w$

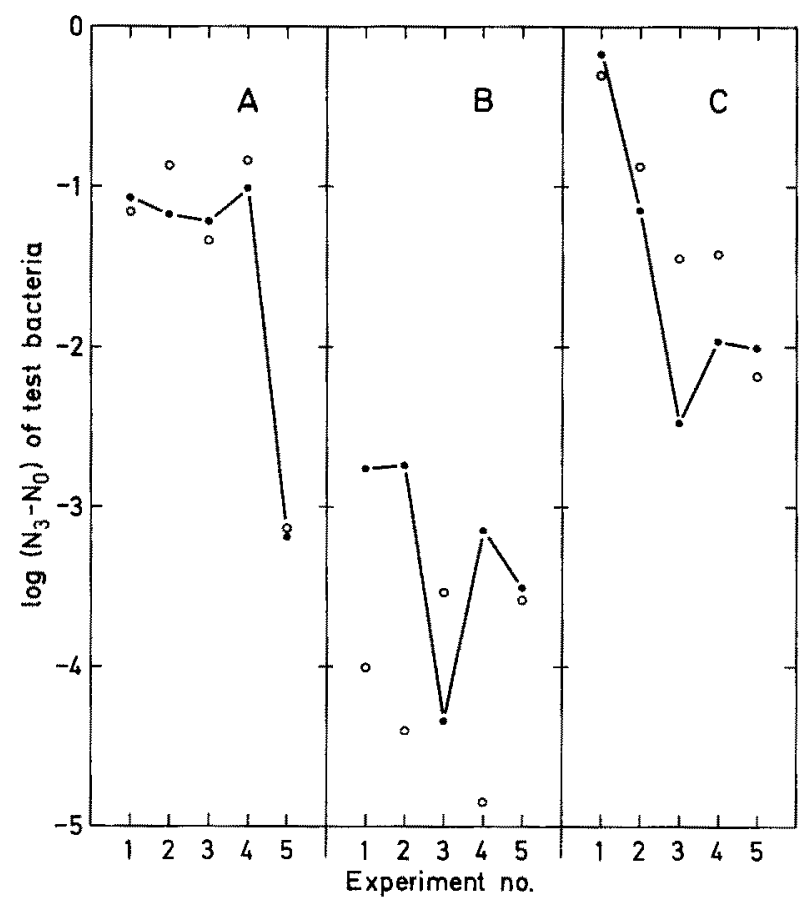

Fig. 1: Escherichia coli, Stapbylococcus aureus and Serratia marinorubra (sections A, B and C, respectively). Inactivation of test bacteria in untreated raw sea water (rsw, - - ), and in $r s w e$ enriched with filter sludge (erszer 0,0 ) as observed after 3 days of incubation at $25^{\circ} \mathrm{C}$ in the dark of $26 \mathrm{ml}$ samples in $200 \mathrm{ml}$ culture flasks. Initial titers of test bacteria were about $10^{8} \mathrm{cells} / \mathrm{ml}$ of $E$. coli, $2 \times 10^{7}$ cells $/ \mathrm{ml}$ of $S$. aureus and $10^{7}$ cells $/ \mathrm{ml}$ of $S$. marinorubra, respectively

and ersw $_{10}$, great differences were observed during 4 experiments. Three times, the inactivation of $S$. aureus was considerably stronger in ersw $w_{10}$ than in $r s w$, in each case correlated with relatively weak inactivation in rsw. Once the opposite occurred.

The last-mentioned finding is of special interest. The experiment in question (exp. $3 / 70$ ) was started on June 12th, one day after the change from a 2-week period of bright sunshine to cloudy and windy weather. The viability of phytoplankton was drastically reduced from one day to the other (Drebes, personal communication). At the same time, an extreme increase in anti-staphylococcal activity of $r s w$ was observed: $\log \left(\mathrm{N}_{3}-\mathrm{N}_{0}\right)$ values obtained during this investigation period were -3.27 (June 5 th), -2.18 (June 8 th), -5.67 (June 12th), -5.94 (June 15th), and -4.86 (June 19th). Dates presented in parenthesis refer to the starts of experiments performed during a 2-year investigation of seasonal changes in antibacterial activity (MoEbus 1972a). The increased anti-staphylococcal activity of $r s w$ might be thought to be due to intensified 
excretion of bactericides by planktonic algae present at that time - mainily Eucampia zoodiacus, Nitzschia seriata and Skeletonema costatum. The two last-mentioned species really are known to produce compounds inhibitory for Staphylococcus aureus under laboratory conditions (AUBERT et al. 1968). However, there are some findings which throw doubts on this interpretation.

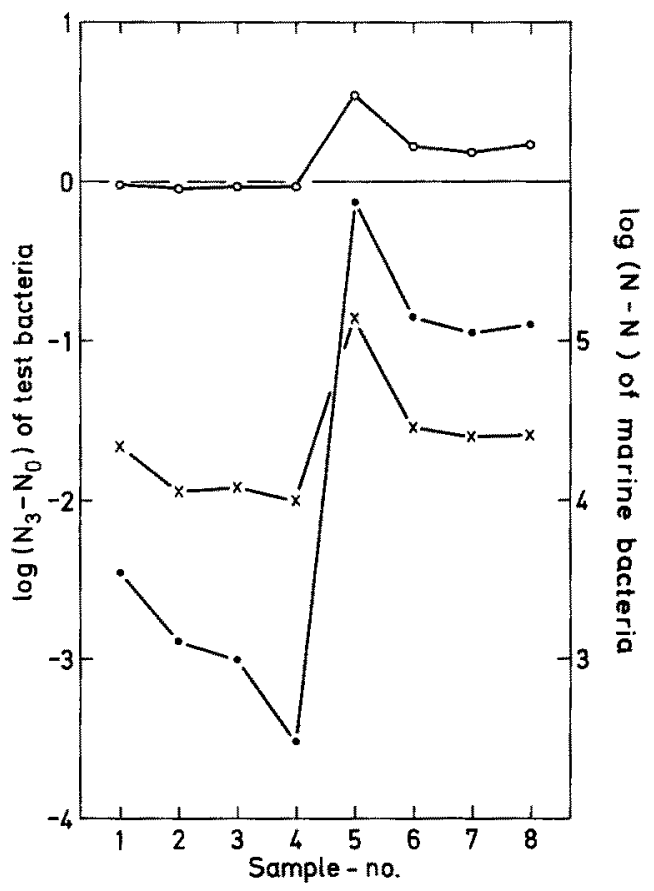

Fig. 2: Stapbylococcus aureus, Serratia marinorubra and marine bacteria. Inactivation on growth of $S$. aureus $(-0)$ and $S$. marinorubra $(0-0)$ as well as of a mixed population of marine bacteria $(X-X)$ as influenced by matter extracted from filter sludge by sterile filtration. Findings obtained after 3 days of incubation at $25^{\circ} \mathrm{C}$ in the dark are shown.

(For detailed information see text)

As shown in Figure 1 (exp. 3, sections $B$ and C), the increased antibacterial activity of rsw against Stapbylococcus aureus and Serratia marinorubra was reduced by addition of filter sludge. This probably occurred as a consequence of increased nutrient concentration in ersw 10 , as indicated by the results of an experiment started on June 15th and performed as follows (Fig. 2): $30 \mathrm{ml} r s w$ were sterile-filtered to obtain sample 1. 2 further portions of $250 \mathrm{ml} r s w$ were sterile-filtered with the same device, each till dryness of the filter disk (samples 2 and 3), without discarding the fsw after withdrawal of sample 2. Sample 4 was prepared by sterile-filtration of $500 \mathrm{ml} \mathrm{rsw}$ with a separate filtering device. Dryness of the filter was avoided until the end of this procedure. Then the filter sludge from both filter disks was scrubbed off in $10 \mathrm{ml} f \mathrm{sw}$ of sample 4. The suspension obtained was added to further $20 \mathrm{ml} f_{s w}$ of sample 4 and subsequently filter-sterilized in a third filtering apparatus (sample 5). Thereupon, 
$80 \mathrm{ml} \mathrm{fsw}$ of sample 4 were sucked through the filter sludge and $20 \mathrm{ml}$ of filtrate (sample 6) were withdrawn. With the remaining filtrate, this procedure was repeated twice to obtain samples 7 and 8 . Three $5.4 \mathrm{ml}$ subsamples of the 8 sterile filtrates were

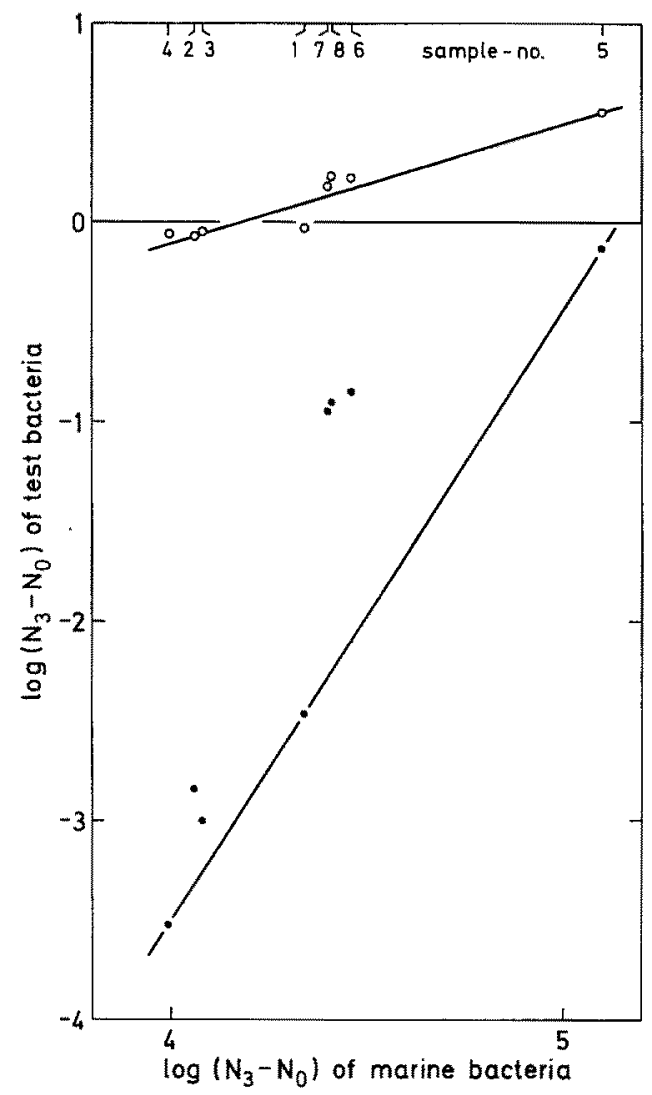

Fig. 3: Stapbylococcus aureus and Serratia marinorubra. Relationships between inactivation or growth of test bacteria and growth of a mixed population of marine bacteria, respectively, in filter-sterilized sea water samples. $S$. aureus: -0, $S$. marinorubra: $0-0$. Same findings as shown in Figure 3. (For further information see text)

dispensed into culture tubes. Two series of subsamples were inoculated with $S$. aureus and $S$. marinorubra, respectively, to about $10^{7} \mathrm{cells} / \mathrm{ml}$. The third series was inoculated with a mixed culture of marine bacteria, obtained by storage of rsw for 3 days at $25^{\circ} \mathrm{C}$ in the dark. The number of colony-forming marine bacteria thereby attained was about $10^{2} / \mathrm{ml}$. Final volume was $6 \mathrm{ml}$ in each case.

The results of this experiment are presented in Figure 2. Obviously, samples 5 to 8 were enriched with nutrients from the filter sludge as indicated by growth of marine bacteria and even of Serratia marinorubra. The decreased inactivation of Stapbylococcus aureus in these samples certainly also was due to nutrient enrichment. Therefrom 
the question arises, whether the observations made from samples 1 to 4 are explainable also on the basis of nutrient concentration. To obtain further information, growth of marine bacteria was plotted versus inactivation or growth of test bacteria, as shown in Figure 3. The straight lines, drawn between extreme values of $\log \left(\mathrm{N}_{3}-\mathrm{N}_{0}\right)$ found in regard to test bacteria, represent linear relations between the findings concerning both groups of bacteria. Although growth of marine bacteria only can be taken as a rough measure of nutrient concentration, the results shown in Figure 3 support the assumption that inactivation of test bacteria in samples 1 to 4 was caused by lower concentrations of available nutrients.

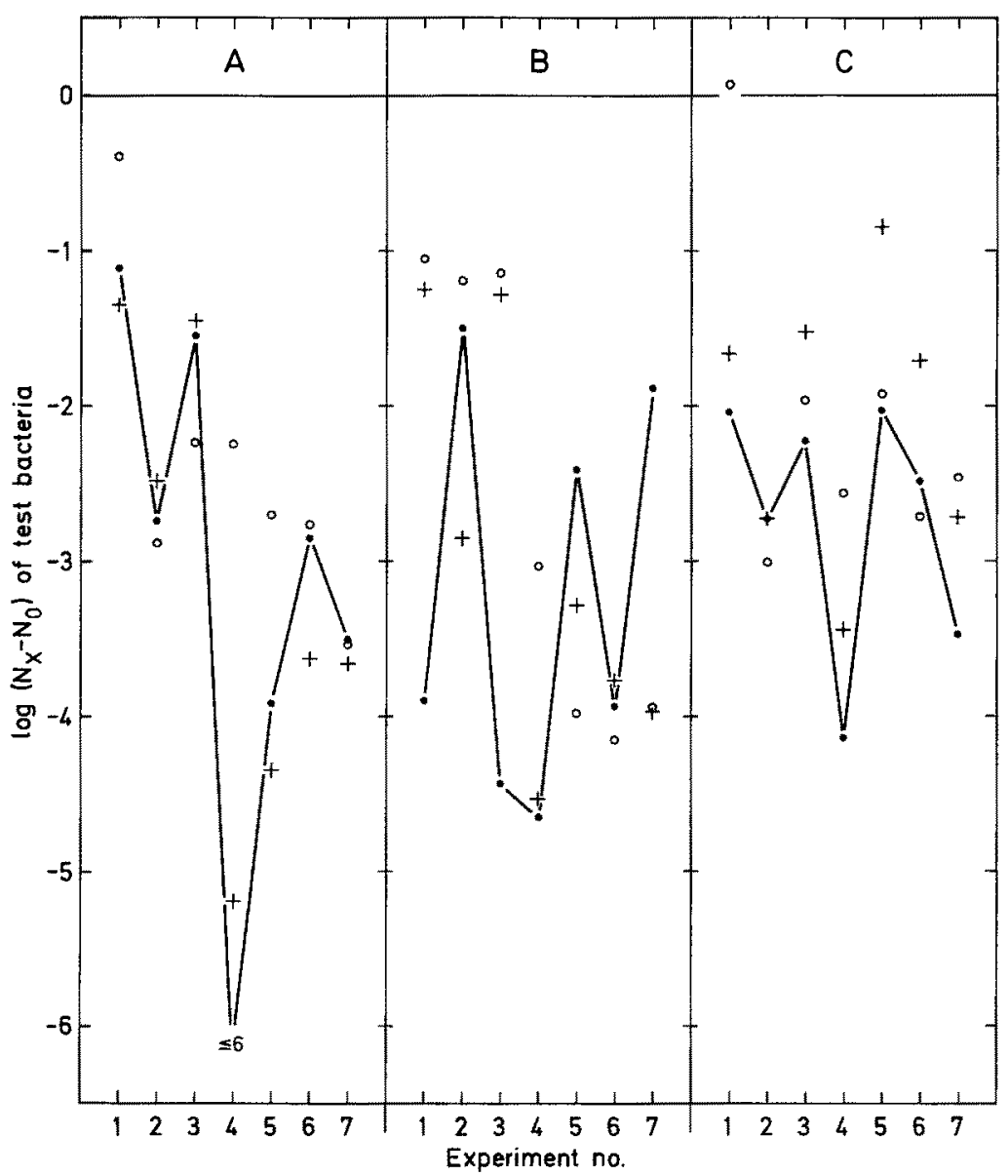

Fig. 4: Escherichia coli, Staphylococcus aureus and Serratia marinorubra (sections $A, B$ and $C$, respectively). Bactericidal capacities of untreated raw sea water (rsw, with viable plankton (erswer, 0 ) and rsw of greatly reduced plankton content $(10,-15,+$ ) respectively, established after incubation at $25^{\circ} \mathrm{C}$ in the dark for 2 days ( $S$. aureus) or 3 days (E. coli, S. marinorubra). About $10^{7}$ cells $/ \mathrm{ml}$ of respective test bacteria were initially present in $10 \mathrm{ml}$ samples filled in culture tubes $(18 \mathrm{~mm} \varnothing)$ 


\section{Effects of viable plankton}

In 1971, the experimental procedure was changed to avoid destruction of planktonic organisms and enrichment of marine bacteria. The tests were performed in culture tubes (18 mm in diameter) each containing 10.0 or $9.5 \mathrm{ml}$ of sea water to be tested. In the latter case, $0.5 \mathrm{ml}$ of test bacterial suspension (in $f(w)$ ) were inoculated to attain initial titers of about $10^{7} \mathrm{cell} / \mathrm{s} / \mathrm{ml}$.

During July to September 1971 , seven experiments were conducted. The results concerning inactivation of test bacteria in the various types of raw and filter-sterilized sea water are summarized in Tables 1, 2 and 3. In Figure 4 with sections A, B and C

Table 1

Escherichia coli. Survival in different types of raw and filter-sterilized sea water, presented as $\log \left(\mathrm{N}_{x}-\mathrm{N}_{0}\right)$ values established after incubation of about $10^{-} \mathrm{cell} / \mathrm{s} / \mathrm{ml}$ at $25^{\circ} \mathrm{C}$ in the dark for $\mathrm{x}$ days. Explanations: $r s w=$ untreated raw sea water, $10 \mu-r s w=r s w$ filtered through $10 \mu$ mesh gauze, ersw20 $=r s w 20$-fold enriched with viable plankton retained by $10 \mu$ mesh gauze; $f s w, 10 \mu-f_{s w}$ and $e f_{s w 2}=$ sterile filtrates prepared from corresponding raw samples; n. d. $=$ not determined

\begin{tabular}{|c|c|c|c|c|c|c|c|}
\hline \multirow{2}{*}{$\begin{array}{c}\text { No. of } \\
\text { experi- } \\
\text { ment }\end{array}$} & \multirow{2}{*}{$\begin{array}{l}\text { Duration } \\
\text { (days) }\end{array}$} & \multicolumn{6}{|c|}{$\log \left(N_{X}-N_{0}\right)$ found from } \\
\hline & & $r s w$ & $10 \mu-r s w$ & erswogo & $f_{s w}$ & $10 \mu-f_{s w e r}$ & $e f s w_{\mathscr{O} 0}$ \\
\hline $1 / 71$ & $\begin{array}{l}1 \\
2 \\
3 \\
4\end{array}$ & $\begin{array}{l}-1.84 \\
-1.43 \\
-2.89 \\
-3.83\end{array}$ & $\begin{array}{r}-1.74 \\
-1.32 \\
-2.66 \\
-5.60 \\
\end{array}$ & $\begin{array}{r}-1.89 \\
-1.87 \\
-1.61 \\
-2.69\end{array}$ & $\begin{array}{l}-1.63 \\
-1.11 \\
-2.46 \\
-3.63\end{array}$ & $\begin{array}{l}\geq 1.27 \\
-1.21 \\
-1.00 \\
-2.59\end{array}$ & $\begin{array}{l}-1.70 \\
-1.63 \\
-1.56 \\
-1.08\end{array}$ \\
\hline $2 / 71$ & $\begin{array}{l}1 \\
2 \\
3 \\
4\end{array}$ & $\begin{array}{r}-1.79 \\
-1.16 \\
-3.27 \\
-5.49 \\
\end{array}$ & $\begin{array}{l}-1.72 \\
-1.18 \\
-3.52 \\
-4.00 \\
\end{array}$ & $\begin{array}{l}-1.69 \\
-2.32 \\
-3.12 \\
-5.54\end{array}$ & $\begin{array}{l}-1.55 \\
-2.17 \\
-3.03 \\
-5.52\end{array}$ & $\begin{array}{r}-1.65 \\
-1.26 \\
-2.59 \\
-3.71\end{array}$ & $\begin{array}{l}-1.16 \\
-2.75 \\
-2.12 \\
-3.36\end{array}$ \\
\hline $3 / 71$ & $\begin{array}{l}1 \\
2 \\
3 \\
4\end{array}$ & $\begin{array}{r}-1.72 \\
-1.00 \\
-2.46 \\
-3.59 \\
\end{array}$ & $\begin{array}{r}-1.62 \\
-1.40 \\
-2.55 \\
-3.20 \\
\end{array}$ & $\begin{array}{r}-1.77 \\
-1.17 \\
-3.77 \\
-4.14 \\
\end{array}$ & $\begin{array}{l}-1.49 \\
-1.10 \\
-2.53 \\
-3.97 \\
\end{array}$ & $\begin{array}{r}-1.39 \\
-1.04 \\
-2.48 \\
-2.04 \\
\end{array}$ & $\begin{array}{l}-1.50 \\
-1.15 \\
-2.77 \\
-2.19 \\
\end{array}$ \\
\hline $4 / 71$ & $\begin{array}{l}1 \\
2 \\
3 \\
4\end{array}$ & $\begin{array}{l}-1.18 \\
-4.04 \\
\leq 6\end{array}$ & $\begin{array}{r}-1.30 \\
-2.04 \\
-6.80 \\
\text { n.d. }\end{array}$ & $\begin{array}{r}-1.64 \\
-2.99 \\
-3.76 \\
-5.57\end{array}$ & $\begin{array}{l}-4.92 \\
\leq 6\end{array}$ & $\begin{array}{l}-3.84 \\
=5.10 \\
\leq 6\end{array}$ & $\begin{array}{l}-1.49 \\
-2.60 \\
-3.36 \\
-5.98\end{array}$ \\
\hline $5 / 71$ & $\begin{array}{l}1 \\
2 \\
3 \\
4\end{array}$ & $\begin{array}{l}-1.54 \\
-2.41 \\
-4.08 \\
\leq 6\end{array}$ & $\begin{array}{l}-1.43 \\
-2.37 \\
-5.65 \\
-6.87 \\
\end{array}$ & $\begin{array}{l}-1.58 \\
-2.92 \\
-3.30 \\
-5.74\end{array}$ & $\begin{array}{l}-1.49 \\
-2.10 \\
-4.54 \\
-5.30\end{array}$ & $\begin{array}{r}-1.60 \\
-1.07 \\
-2.66 \\
-2.06\end{array}$ & $\begin{array}{l}-1.17 \\
-2.70 \\
-3.88 \\
-3.13\end{array}$ \\
\hline $6 / 71$ & $\begin{array}{l}1 \\
2 \\
3 \\
4\end{array}$ & $\begin{array}{l}-1.67 \\
-1.02 \\
-3.15 \\
\leq 6\end{array}$ & $\begin{array}{l}-1.62 \\
-2.59 \\
-4.38 \\
\leq 6\end{array}$ & $\begin{array}{l}-1.61 \\
-1.14 \\
-3.24 \\
-4.24\end{array}$ & $\begin{array}{l}-1.66 \\
-2.90 \\
-2.32 \\
-3.52 \\
\end{array}$ & $\begin{array}{r}-1.13 \\
-3.99 \\
-4.96 \\
-5.98\end{array}$ & $\begin{array}{l}-1.62 \\
-1.06 \\
-2.48 \\
-3.87\end{array}$ \\
\hline 7/71 & $\begin{array}{l}1 \\
2 \\
3 \\
4\end{array}$ & $\begin{array}{l}-1.73 \\
-2.95 \\
\leq 4.50 \\
\leq 6\end{array}$ & $\begin{array}{l}-1.65 \\
-2.65 \\
-4.34 \\
\leq 6\end{array}$ & $\begin{array}{l}-1.69 \\
-2.87 \\
-4.47 \\
\leq 6\end{array}$ & $\begin{array}{l}-1.77 \\
-2.96 \\
-4.75 \\
-6.60\end{array}$ & $\begin{array}{l}-2.01 \\
=5.63 \\
\leq 6\end{array}$ & $\begin{array}{l}-1.66 \\
-1.04 \\
-4.83 \\
-5.83\end{array}$ \\
\hline
\end{tabular}


referring to Escherichia coli, Stapbylocaccus aureus and Serratia marinorubra, respectively, findings obtained from $r s w, 10 \mu$-rsw and ersw $w_{20}$ are demonstrated. (Note: Regarding $S$, aureus, findings ascertained after only 2 days of incubation are shown.) As found by enrichment with filter sludge, $S$. aureus was the only test strain, the inactivation of which sometimes was stronger in ersw $w_{20}$ than in rsw. The opposite, however, was observed for each test strain during several experiments. Regarding $10 \mu$-rsw, the expected decrease in antibacterial activity rather regularly was found only for S. marinorubra. Some observations are of special interest.

Experiment $1 / 71$ was performed with a sea-water sample rich in phyto- and zooplankton, the latter mainly consisting of a protozoon ( 1 to 2 organisms $/ \mathrm{ml}$ ) which dies within about 2 hours of incubation at $25^{\circ} \mathrm{C}$. Most abundant planktonic algae were Chaetoceros socialis and Rbizosolenia delicatula (each up to $10^{5}$ cells/1). Eucampia zoodiacus, Cerataulina bergonii, Chaetoceros debilis and Thalassiosira rotula were persent in numbers up to $10^{4}$ cells $/ 1$. Among these algal species $C$. socialis is known to produce anti-staphylococcal substance(s) (Aunert et al. 1968). As can be seen from

Table 2

Staphylococcus aureus. Survival in different types of raw and filter-sterilized sea water.

(For further information see Table 1)

\begin{tabular}{|c|c|c|c|c|c|c|c|}
\hline \multirow{2}{*}{$\begin{array}{l}\text { No. of } \\
\text { experi- } \\
\text { ment }\end{array}$} & \multirow{2}{*}{$\begin{array}{l}\text { Duration } \\
\text { (days) }\end{array}$} & \multicolumn{6}{|c|}{$\log \left(\mathrm{N}_{\mathrm{x}}-\mathrm{N}_{0}\right)$ found from } \\
\hline & & $r s w$ & $10 \mu-r s w$ & $\operatorname{ersw}_{2 \theta}$ & $f_{s w}$ & $10 \mu-f_{s} w$ & efsw $s w_{20}$ \\
\hline $1 / 71$ & $\begin{array}{l}1 \\
2 \\
3\end{array}$ & $\begin{array}{l}-1.75 \\
-4.11 \\
-5.02\end{array}$ & $\begin{array}{l}-1.92 \\
-2.75 \\
-6.87\end{array}$ & $\begin{array}{l}+0.06 \\
-2.96 \\
-5.86\end{array}$ & $\begin{array}{l}-1.37 \\
-2.20 \\
-4.75\end{array}$ & $\begin{array}{l}-1.87 \\
-1.19 \\
-2.29\end{array}$ & $\begin{array}{l}-1.93 \\
-1.49 \\
-2.77\end{array}$ \\
\hline $2 / 71$ & $\begin{array}{l}1 \\
2 \\
3\end{array}$ & $\begin{array}{l}-1.80 \\
-2.50 \\
-5.41\end{array}$ & $\begin{array}{l}-1.76 \\
-3.15 \\
-5.58\end{array}$ & $\begin{array}{l}-1.80 \\
-2.81 \\
-5.77\end{array}$ & $\begin{array}{l}-1.41 \\
\leq 4.45 \\
\leq 6\end{array}$ & $\begin{array}{l}-1.46 \\
-3.22 \\
-5.54\end{array}$ & $\begin{array}{l}-1.54 \\
-2.32 \\
-4.97\end{array}$ \\
\hline $3 / 71$ & $\begin{array}{l}1 \\
2 \\
3\end{array}$ & $\begin{array}{l}-1.66 \\
-5.57 \\
-6.45\end{array}$ & $\begin{array}{l}-1.85 \\
-2.72 \\
-4.55 \\
\end{array}$ & $\begin{array}{l}-1.87 \\
-2.86 \\
-5.78 \\
\end{array}$ & $\begin{array}{l}-1.11 \\
-4.31 \\
-6.75 \\
\end{array}$ & $\begin{array}{l}-1.74 \\
-2.40 \\
-3.06 \\
\end{array}$ & $\begin{array}{l}-1.59 \\
-2.32 \\
-4.63 \\
\end{array}$ \\
\hline $4 / 71$ & $\begin{array}{l}1 \\
2 \\
3 \\
\end{array}$ & $\begin{array}{l}-1.80 \\
-5.35 \\
\leq 6\end{array}$ & $\begin{array}{l}-1.21 \\
=5.47 \\
\leq 6\end{array}$ & $\begin{array}{r}-1.99 \\
-4.97 \\
-6.77 \\
\end{array}$ & $\begin{array}{l}-2.80 \\
\leq 4.47 \\
\leq 6 \\
\end{array}$ & $\bar{x}_{6}^{4.37}$ & $\begin{array}{l}-1.63 \\
-3.18 \\
\leq 6 \\
\end{array}$ \\
\hline $5 / 71$ & $\begin{array}{l}1 \\
2 \\
3 \\
4 \\
\end{array}$ & $\begin{array}{r}-1.77 \\
-3.59 \\
-5.36 \\
-6.92 \\
\end{array}$ & $\begin{array}{r}-1.39 \\
-4.72 \\
\simeq 6.0 \\
\text { n.d. }\end{array}$ & $\begin{array}{r}-1.77 \\
-4.02 \\
-5.06 \\
-6.86 \\
\end{array}$ & $\begin{array}{r}-1.94 \\
-2.64 \\
-3.59 \\
-4.04 \\
\end{array}$ & $\begin{array}{l}-1.84 \\
-2.04 \\
-4.45 \\
\leq 6 \\
\end{array}$ & $\begin{array}{l}-1.75 \\
-1.13 \\
-2.23 \\
-5.84 \\
\end{array}$ \\
\hline $6 / 71$ & $\begin{array}{l}1 \\
2 \\
3 \\
4 \\
\end{array}$ & $\begin{array}{l}-2.86 \\
-4.07 \\
-5.08 \\
\leq 6\end{array}$ & $\begin{array}{l}-1.60 \\
=4.23 \\
\leq 6\end{array}$ & $\begin{array}{l}-1.75 \\
-5.85 \\
-6.83 \\
\leq 6 \\
\end{array}$ & $\begin{array}{l}-3.95 \\
-4.68 \\
-5.64 \\
\leq 6\end{array}$ & $\begin{array}{l}-1.90 \\
-1.65 \\
-2.83 \\
-4.31 \\
\end{array}$ & $\begin{array}{l}-1.74 \\
-2.79 \\
-2.00 \\
-4.49\end{array}$ \\
\hline $7 / 71$ & $\begin{array}{l}1 \\
2 \\
3 \\
4\end{array}$ & $\begin{array}{r}-1.79 \\
-2.12 \\
-6.85 \\
\text { n.d. }\end{array}$ & $\begin{array}{l}-2.81 \\
=4.03 \\
\leq 6\end{array}$ & $\begin{array}{r}-1.86 \\
-4.06 \\
-6.70 \\
\text { n.d. }\end{array}$ & $\begin{array}{l}-1.12 \\
-3.51 \\
-4.42 \\
-5.45\end{array}$ & $\begin{array}{l}-2.35 \\
-3.46 \\
-4.59 \\
-5.68\end{array}$ & $\begin{array}{l}-2.74 \\
-3.67 \\
-5.29 \\
\leq 6\end{array}$ \\
\hline
\end{tabular}


Figure 4, enrichment of viable plankton in ersw greatly reduced the antibacterial activity of rsw. Serratia marinorubra was able to grow even in ersw20 (and in ef $s w_{20}$, Table 3).

The water samples used in experiments $2 / 71$ and $3 / 71$, respectively, were extremely poor in planktonic organisms. However, the latter was rich in detritus and sediment particles. In both samples, Ceratium fusus and $C$. furca were the most abundant algae. Diatom species were present in numbers below $10^{3} \mathrm{cells} / \mathrm{l}$. The most important observation made during these 2 experiments refers to inactivation of Staphylococcus aureus, which was stronger in fsw than in rsw during experiment $2 / 71$.

Experiment $4 / 71$ was performed with a sea-water sample containing extraordinarily large amounts of phytoplankton which was in excellent condition. The enrichment procedure required about 1 hour (the longest time ever needed). Unfortunately, no quantitative information upon planktonic algae is available in respect to this and

Table 3

Serratia marinorubra. Survival in different types of raw and filter-sterilized sea water. (For further information see legend to Table 1)

\begin{tabular}{|c|c|c|c|c|c|c|c|}
\hline \multirow{2}{*}{$\begin{array}{l}\text { No. of } \\
\text { experi- } \\
\text { ment }\end{array}$} & \multirow{2}{*}{$\begin{array}{c}\text { Duration } \\
\text { (days) }\end{array}$} & \multicolumn{6}{|c|}{$\log \left(\mathrm{N}_{\mathrm{X}}-\mathrm{N}_{0}\right)$ found from } \\
\hline & & $r s w$ & $10 \mu-r s w$ & erswego & fsw & $10 u-f s w$ & $e f s w_{20}$ \\
\hline $1 / 71$ & $\begin{array}{l}1 \\
2 \\
3 \\
4\end{array}$ & $\begin{array}{l}-1.98 \\
-1.77 \\
-3.97 \\
-4.46\end{array}$ & $\begin{array}{l} \pm 0 \\
-1.88 \\
-2.34 \\
-3.27\end{array}$ & $\begin{array}{l}+0.29 \\
+0.27 \\
+0.07 \\
+0.07\end{array}$ & $\begin{array}{l} \pm 0 \\
-1.96 \\
-1.91 \\
-1.87\end{array}$ & $\begin{array}{l} \pm 0 \\
-1.95 \\
-1.91 \\
-1.86\end{array}$ & $\begin{array}{l}+0.12 \\
+0.11 \\
+0.07 \\
+0.04\end{array}$ \\
\hline $2 / 71$ & $\begin{array}{l}1 \\
2 \\
3 \\
4\end{array}$ & $\begin{array}{l}-1.94 \\
-1.27 \\
-3.28 \\
-4.43\end{array}$ & $\begin{array}{l}-1.87 \\
-1.27 \\
-3.28 \\
-4.98\end{array}$ & $\begin{array}{l}-1.91 \\
-1.36 \\
-4.99 \\
-4.55\end{array}$ & $\begin{array}{l}-1.95 \\
-1.85 \\
-1.64 \\
-1.39\end{array}$ & $\begin{array}{r}-1.95 \\
-1.89 \\
-1.93 \\
-1.92\end{array}$ & $\begin{array}{l}-1.88 \\
-1.89 \\
-1.86 \\
-1.84\end{array}$ \\
\hline $3 / 71$ & $\begin{array}{l}1 \\
2 \\
3 \\
4\end{array}$ & $\begin{array}{l}-1.97 \\
-1.83 \\
-3.78 \\
-4.79\end{array}$ & $\begin{array}{l}-1.94 \\
-1.78 \\
-2.48 \\
-3.47\end{array}$ & $\begin{array}{l}-1.98 \\
-1.82 \\
-2.04 \\
-4.62\end{array}$ & $\begin{array}{r}+0.10 \\
+0.10 \\
+0.13 \\
+0.11\end{array}$ & $\begin{array}{l}-1.95 \\
-1.93 \\
-1.96 \\
-1.88\end{array}$ & $\begin{array}{l} \pm 0 \\
\pm 0 \\
=1.98 \\
-1.94\end{array}$ \\
\hline $4 / 71$ & $\begin{array}{l}1 \\
2 \\
3 \\
4 \\
\end{array}$ & $\begin{array}{l}-1.90 \\
-1.36 \\
-5.87 \\
-5.19 \\
\end{array}$ & $\begin{array}{l}-1.95 \\
-1.68 \\
-4.56 \\
-5.05\end{array}$ & $\begin{array}{l}-1.92 \\
-1.56 \\
-3.44 \\
-4.00\end{array}$ & $\begin{array}{l}-1.95 \\
-1.92 \\
-1.82 \\
-1.74\end{array}$ & $\begin{array}{l}-1.88 \\
-1.39 \\
-2.98 \\
-2.65\end{array}$ & $\begin{array}{l}-1.73 \\
-1.32 \\
-2.98 \\
-2.74\end{array}$ \\
\hline $5 / 71$ & $\begin{array}{l}1 \\
2 \\
3 \\
4\end{array}$ & $\begin{array}{l}-1.95 \\
-1.75 \\
-3.98 \\
-3.45\end{array}$ & $\begin{array}{l}-1.98 \\
-1.91 \\
-1.15 \\
-3.22\end{array}$ & $\begin{array}{l}-1.90 \\
-1.69 \\
-2.08 \\
-3.81\end{array}$ & $\begin{array}{l} \pm 0 \\
-1.91 \\
-1.80 \\
-1.70\end{array}$ & $\begin{array}{r}-1.97 \\
-1.96 \\
-1.92 \\
-1.84\end{array}$ & $\begin{array}{l}-1.94 \\
-1.90 \\
-1.88 \\
-1.86\end{array}$ \\
\hline $6 / 71$ & $\begin{array}{l}1 \\
2 \\
3 \\
4\end{array}$ & $\begin{array}{l}-1.95 \\
-1.49 \\
-3.52 \\
-4.44\end{array}$ & $\begin{array}{l}-1.96 \\
-1.87 \\
-2.29 \\
-3.39\end{array}$ & $\begin{array}{l}-1.90 \\
-1.59 \\
-3.29 \\
-4.43\end{array}$ & $\begin{array}{l}-1.97 \\
-1.93 \\
-1.87 \\
-1.84\end{array}$ & $\begin{array}{r}-1.93 \\
-1.93 \\
-1.90 \\
-1.86\end{array}$ & $\begin{array}{l}-1.95 \\
-1.91 \\
-1.88 \\
-1.84\end{array}$ \\
\hline $7 / 71$ & $\begin{array}{l}1 \\
2 \\
3 \\
4\end{array}$ & $\begin{array}{l}-1.90 \\
-1.20 \\
-4.53 \\
-5.27\end{array}$ & $\begin{array}{l}-1.95 \\
-1.56 \\
-3.28 \\
-5.80\end{array}$ & $\begin{array}{l}-1.97 \\
-1.50 \\
-3.54 \\
-5.82\end{array}$ & $\begin{array}{l}-1.95 \\
-1.89 \\
-1.81 \\
-1.59\end{array}$ & $\begin{array}{r}-1.96 \\
-1.92 \\
-1.66 \\
-1.51\end{array}$ & $\begin{array}{l} \pm 0 \\
-1.92 \\
-1.78 \\
-1.73\end{array}$ \\
\hline
\end{tabular}


the following experiments. According to own observations, Chatoceros socialis and several Rbizosolenia species were most frequent, but Asterionella japonica, Eucampia zoodiacus and Bidulpbia spec. were also numerous. At least $C$. socialis and $A$. japonica are capable of producing bactericides. During this experiment, the inactivation of each test strain was considerably weaker in ersw $w_{20}$ than in rsw and $10 \mu$-rsw. However, more important are the observations made from the respective sterile filtrates (Tables 1 , 2 and 3). Against Escherichia coli and Staphylococcus aureus, the filtrates were at least as effective as the corresponding raw waters. Serratia marinorubra was inactivated to lesser degrees but its kill in $10 \mu$-fsw and efsw2 was the strongest ever observed during this investigation.

Experiments 5/71 to $7 / 71$ were performed with sea-water samples considerably poorer in phytoplankton than the sample used in experiment $4 / 71$. The plankton enrichment procedures required only about $35 \mathrm{~min}$. Rbizosolenia shrubsolei was by far the most predominant in sample 5/71, whereas samples $6 / 71$ and $7 / 71$ contained no clearly dominant algal species. The most striking observation made during these experiments concerns identical inactivation of Escherichia coli and Serratia marinorubra, respectively, in all 3 types of raw sea water during 4 days of incubation (Tables 1 and 3 , exp. 7/71).

\section{Observations concerning marine bacteria}

Some findings of general interest were obtained in regard to colony-forming marine bacteria as summarized in the following.

(1) By enrichment of $r s w$ with filter sludge, the number of colony formers was increased in ersw $w_{10}$ by $100 \%$ to $600 \%$. The smallest increase in bacterial numbers was observed from ersw $w_{10}$ used in experiment $3 / 70$ (Fig. 1). Since the enrichment procedure was always the same, inactivation of marine bacteria during preparation of filter sludge must be taken into account.

(2) The preparation of ersw $w_{20}$ by inverse filtration was accompanied by enrichments of marine bacteria ranging from $50 \%$ to $200 \%$ of colony formers present in rsw. The rise in bacterial numbers was independent of the phytoplankton mass contained in rsw. Increases by $200 \%$ were found in experiment $4 / 71$ and $6 / 71$.

(3) The bacterial content of $10 \mu-r s w$ mostly was the same as, or $20 \%$ to $40 \%$ smaller than, found from $r s w$.

(4) After incubation of raw sea-water samples, the relative number of marine bacteria forming colonies of at least $1.5 \mathrm{~mm}$ in diameter during 5 days of incubation at $25^{\circ} \mathrm{C}$ on $2216 \mathrm{E}$-agar was found generally to be greater in ersw $w_{10}$ and $e r s w_{20}$ than in rswe or $10 \mu$-rsw. (1.5 $\mathrm{mm}$ is an arbitrarily chosen measure.) According to JANNASCHs (1968) findings, predominance of large colonies of marine bacteria can be ascribed, at least in part, to increased nutrient concentration supporting selective enrichment of respective bacterial species during growth of mixed populations. Therefore, it is of interest that bacteria forming such large colonies were found to dominate in each of the different types of raw sea water used during experiments $3 / 70$ and $4 / 71$. Both 
experiments are characterized by strong antibacterial activity of $r s w$ but considerably weaker kill of test bacteria in ersw 10 and ersw $w_{20}$, respectively.

(5) After incubation of the various types of raw sea water, largest numbers of colony-forming marine bacteria/ml generally were found from ersw $w_{10}$ and erswo. In ersw $_{20}$, maximum numbers mostly were attained after one day. Decrease in colony formers $/ \mathrm{ml}$ of at least one order of magnitude during the following 3 days of incubation was a common observation. It occurred independently of the presence or absence of test bacteria as well as of the bactericidal effect of ersw20. In 1970 (Fig. 1), only three times were similar observations made from ersw $w_{10}$, however, each in correla-tion with a beneficial effect of filter sludge enrichment for Staphylococcus aureus (exp. $3 / 70$ ) and Serratia marinorubra (exps. 3/70 and 4/70), respectively. Growth of marine bacteria in rsw and $10 \mu-r s w$ lasted for 2 or 3 days and was followed by relatively small decreases in bacterial numbers $/ \mathrm{ml}$. After 4 days of incubation, mostly rather similar numbers of colony formers/ml were established for $r s w, 10 \mu-r s w$ and ersw $w_{20}$. Finally, ist must be mentioned that, from nearly each tested sample of the 3 types of raw sea water during experiment $4 / 71$, larger numbers of marine bacteria were found than during the other experiments of the 1971 series. This was essentially independent of the presence of test bacteria and is also indicative of increased amounts of nutritive matter present in sea water at that time.

(6) During experiments $1 / 71$ to $6 / 71$, marine bacteria were observed which developed giant colonies spreading over the whole surface of $2216 \mathrm{E}$-agar. Sometimes the number $/ \mathrm{ml}$ of these bacteria was increased after plankton enrichment. During incubation they failed to grow in $10 \mu-r s w$ but multiplied most rapidly in ersw2o. In the presence of Serratia marinorubra, growth of these organisms was considerably repressed in $r s w$ but scarcely in $e r s w w_{20}$.

\section{DISCUSSION}

Numerous planktonic algal species are known to produce bactericidal compounds under natural and laboratory conditions. Findings referring thereto are based essentially on enrichments of algae either from their natural habitats or in uni-algal cultures. Therefore, our knowledge regarding the actual ecological relevance of biogenic bactericides is limited. In this respect, the observation of seasonal changes in antibacterial activity of sea water (Sirburth \& Pratt 1962, Moebus 1972a), correlated with the life cycles of phytoplankton communities, is of special importance. Increased bactericidal capacity of sea water at times of phytoplankton blooms or break-downs is generally thought to be indicative of effective concentrations of compounds a priori harmful for the test organisms used. However, this conclusion is doubtful for several reasons.

The antibacterial activity of sea water as observed by laboratory tests cannot be put on a level with the bactericidal capacity really existing at the time of sea-water sampling, since gross changes in water quality occur during the tests. These variations are due to metabolic activities of living beings, to lysis of dead or dying organisms, and 
presumably to some other processes. Therefore, it seems reasonable to base any conclusions regarding effects of bactericides on findings obtained by tests of sterile filtrates. These contain the soluble fraction of organic matter present at any time, at least a part of which may be bactericidal. As reported by MoEsus (1972a), considerable variations in antibacterial activity of $f_{s w}$ were found, likewise correlated with the development of phytoplankton, but the changes in bactericidal effects of $r s w$ and $f s w$ often were of opposite tendencies. By these observations (and others) the antibacterial activity of rsw was demonstrated clearly to be influenced by living and/or dead particulate matter during the tests themselves. However, by the same findings, the importance of bactericidal products of marine organisms was called in question. This becomes evident by the fact that sometimes the kill of Stapbylococcus aureus was stronger in $f$ sw than in rswer. Meanwhile similar findings were obtained for Escherichia coli.

Manifold observations reported by MoEBus $(1972 a$, b) point to the involvement of nutritive matter in test bacterial kill in sea water. Results of further investigations support this view (Moenus 1972c). The bactericidal effect of sterile sea water could be increased by addition of low amounts of organic nutrients. Peptone was most effective at final concentrations below $10^{-4} \mathrm{mg} / \mathrm{ml}$. Changes in concentration of useful nutrients (amino acids, sugars and others) even at these low levels must be expected to occur under natural conditions, as indicated by the findings of RILEY \& SEGAR (1970) concerning amino acids. Therefore, seasonal changes in antibacterial activity of $f_{s w}$ may be due to variations in concentration and nature of nutritive substances, which on their part greatly depend upon phytoplankton development. In $r s w$, the influence of nutrients on the survival of test organisms certainly is superimposed, mainly by activities of marine bacteria as food consumption and excretion of harmful substances.

The present findings support this view. Although the inactivation of Stapbylococcus aureus was increased sometimes by addition of filter sludge or viable plankton, these findings cannot be indicative of increased concentrations of bactericides caused by such additions. Otherwise, removal of plankton should have produced decreased anti-staphylococcal activity of $10 \mu-r s w$ during respective experiments. This was not the case. During other experiments, the effects of filter sludge or viable plankton on survivability of $S$. aureus were either negligible or even favourable. Such findings were common for both other test strains.

It is of special interest that beneficial influences of enrichments were most pronounced at times of greatly increased antibacterial activity of rsw. During experiment 4/71 this was found to be correlated with likewise increased activity of $f$ sw against Escherichia coli and Staphylococcus aureus. Inactivation of $E$. coli even was stronger in $f$ sw than in $r s w$. At first sight, the latter findings may be thought to suggest large amounts of bactericides present. However, such an assumption is inconsistent with the findings obtained from the 3 types of raw sea water. Apart from the fact that plankton enrichment resulted in decreased bactericidal capacity of erswa, observations regarding marine bacterial growth are indicative of increased nutrient concentration at that time. Marine bacteria forming large colonies on $2216 \mathrm{E}$-agar were dominant in each type of raw sea water tested, and growth of marine bacteria in $r s w, 10 \mu$-rsw and ersw $w_{20}$ mostly exceeded that found from analogous samples during the other experiments of the 1971 series. The strong antibacterial activity of sterile filtrates observed 
during experiment $4 / 71$, therefore, is attributed to increased concentration of available nutrients produced by the large mass of phytoplankton present in the sea-water sample used. This statement is in agreement with findings obtained from experimentally enriched sterile, natural and synthetic sea water (MOEBus 1972c).

If this interpretation corresponds to reality - and this is my opinion - the different results established for the 3 test bacterial species after incubation in sterile filtrates must be attributed essentially to strain-specific properties such as food requirements, capability to use nutrients from sea water and sensitiveness to inorganic constituents of this medium. The importance of both last-mentioned factors is suggested by recently reported observations (MoEbus 1972c). In raw sea waters, several other parameters, such as release and consumption of nutrients as well as competition for food, are additionally involved in test bacterial kill. Competition for nutrients between marine and test bacteria was found to be considerable importance, at least in regard to Serratia marinorubra (Moebus 1972a, c).

Interpretation of antibacterial activity of sea water solely on the basis of biological findings is always an extremely difficult task since, with absolute certainty, various factors are involved simultaneously in inactivation of non-marine bacteria. With the exception of salinity, no important parameter remains nearly constant, neither under natural conditions nor during the tests lasting a few days. Therefore, one can only attempt to estimate the relative importance of the different factors. According to recent results (Moebus 1972a, b, c). I think that the importance of biogenic bactericides, present at the time of water sampling, in regard to self-purification of the sea is considerably overestimated. This statement is supported by the findings reported in this paper. Although co-operation of bactericidal products of planktonic algae in inactivation of test bacteria cannot be excluded, most results obtained during this investigation suggest dominant effects of available nutrients, which are superimposed by activities of marine bacteria, at least under laboratory conditions.

\section{SUMMARY}

1. Antibacterial activity of sea water against Escherichia coli, Staphylococcus aureus and Serratia marinorubra, as influenced by enrichment with filter sludge or viable plankton as well as by removal of plankton, was investigated. Inactivation of $S$. aureus only was sometimes increased by the enrichments employed.

2. During several experiments, inactivation of the 3 test strains was considerably decreased by enrichment with dead or living particulate matter. Most striking effects of this kind were observed at times of greatly increased bactericidal capacity of untreated sea water.

3. Sometimes, the inactivation of Escherichia coli and Stapbylococcus aureus in sterile filtrates, prepared from the different types of raw sea water used, was the same as or even stronger than in corresponding samples of raw sea water.

4. From the present findings, it is concluded that bactericidal products of planktonic algae in regard to antibacterial activity of sea water are less important than available nutrients. 
Acknowledgements. This investigation was supported by the Deutsche Forschungsgemeinschaft and by the Biologische Anstalt Helgoland. Data concerning phytoplankton were made available by Dr. G. Drebes. Reliable help of Mr. J. Nitsche is gratefully acknowledged.

\section{LITERATURE CITED}

Aubert, J. \& Jorris, C., 1971. Action antibiotique de quelques espèces phytoplanctoniques marines vis-a-vis de différentes salmonelles. Rev. int. Océanogr. méd. 22-23, 143-147.

- Aubert, M. \& Gauthier, M., 1968. Pouvoir autoepurateur de l'eau de mer et substances antibiotiques produites par les organismes marins. Rev. int. Océanogr. méd. 10, 137-207.

- \& Pesando, D., 1969. Variations de l'action antibiotique de souches phytoplanctoniques en function de rhythmes biologiques marins. Rev. int. Océanogr. méd. 15-16, 29-40.

Carlucci, A. F., Scarpino, P. V. \& Pramer, D., 1961. Evaluation of factors affecting the survival of Escherichia coli in sea water. V. Studies with heat- and filter-sterilized sea water. Appl. Microbiol. 9, 400-404.

GaUTHIER, M., 1969. Activité antibactérienne d'une diatomée marine: Asterionella notata (Grun.) Rev. int. Océanogr. méd. 15-16, 103-171.

GIAXA, W. DE, 1889. Uber das Verhalten einiger pathogener Mikroorganismen im Meerwasser. Z. Hyg. InfektKrankh. 6, 162-225.

JANNASCH, H., 1968. Growth characteristics of heterotrophic bacteria in sea water. J. Bact. 95, $722-723$.

Moebus, K., 1972a. Seasonal changes in antibacterial activity of North Sea water. Mar. Biol. 13, 1-13.

- 1972b. The influence of storage on antibacterial activity of sea water. I. Experiments with sea water stored at $18^{\circ} \mathrm{C}$. Mar. Biol. 13, 346-351.

- 1972c. Bactericidal properties of natural and synthetic sea water as influenced by addition of low amounts of organic matter. Mar. Biol. (In press).

Rrley, J. P. \& Segar, D. A., 1970. The seasonal variation of the free and combined dissolved amino acids in the Irish Sea. J. mar. biol. Ass. U.K. 50, 713-720.

SIEBURTH, J., 1968. The influence of algal antibiosis on the ecology of marine microorganisms. In: Advances in microbiology of the sea. Ed. by M. R. Droop \& E. J. F. Wood. Academic Press, New York, 1, 63-94.

- PRATT, D. M., 1962. Anticoliform activity of sea water associated with the termination of Skeletonema costatum blooms. Trans. N.Y. Acad. Sci. 24, 498-501.

VacCaro, R. F., Briggs, M. P., CAREY, C. L. \& Ketchum, B. H., 1950. Viability of Escherichia coli in sea water. Am. J. publ. Hlth 40, 1257-1266.

ZoBell, C. E., 1936. Bactericidal action of sea water. Proc. Soc. exp. Biol. Med. 34, 113-116.

Author's address: Dr. K. Moebus

Biologische Anstalt Helgoland (Meeresstation)

2192 Helgoland

Federal Republic of Germany 